\title{
Training Needs for the Professional Development of Social-Studies Teachers at the Intermediate Stage in Al-Jouf in Light of Modern Teaching Trends: A Field Study
}

\author{
Yousef Ogla Almarshad ${ }^{1}$ \\ ${ }^{1}$ College of Education, Aljouf University, Sakaka Aljouf, Saudi Arabia \\ Correspondence: Yousef Ogla Almarshad, College of Education, Aljouf University, Sakaka Aljouf, Saudi Arabia. \\ E-mail: dralmarshad@gmail.com
}

Received: April 23, 2016

Accepted: December 31, 2016

Online Published: January 10, 2017

doi:10.5539/jel.v6n2p171

URL: http://dx.doi.org/10.5539/jel.v6n2p171

\begin{abstract}
This study is an attempt to identify the training needs of social-studies teachers at the intermediate stage in Al-Jouf in light of modern teaching trends. It focuses on the six axes of systemic planning, varied teaching strategies, information and communication technology, innovative enrichment activities in teaching, classroom-management skills, and diverse assessment methods. Its subjects are 60 male teachers and 60 female teachers carefully selected for the application of the final form of the questionnaire. It relies on 9 tables showing the cities and axes of the study, the training needs for each axis, and the analyses of findings. It finally provides a number of suggestions and recommendations for further future field studies in the Kingdom of Saudi Arabia. In other words, the present study is a kind of investigation into the training needs of the target teachers with an aim to enhance their professional development in an age characterize by its rabid change and great technological advances.
\end{abstract}

Keywords: training needs, professional development, social-studies teachers, modern teaching trends, educational systems

\section{Introduction}

Because of the world's rabid change and the continuing technological advance, educationalists are obliged to search for ways to overcome the challenges of the twenty-first century. One way to reach this end is to examine the educational systems and remedy the elements that suffer defects. In this situation, in-service teachers are given so much attention that identifying their training needs becomes the major worry of so many countries. Bill Clinton's document issued in February 1997 is a good manifestation as Clinton asserts that his absolute priority in the next years is to make sure that Americans get the best education in the world. He sets ten principles on which American education should rest including the one that there should be a talented cooperative teacher in every grade to get a highly qualitative education (Al-Hor \& Kamal, 2003). That is why modification of programs is a necessary process in addition to identifying the training needs of teachers that automatically change with the emergence of new teaching trends.

\section{Methods}

\subsection{Question and Plan of the Study}

Since the teacher is an essential component of the educational system, identifying his training needs becomes of paramount importance. Field studies prove to be viable in diagnosing and curing the defects of teachers in an age characterized by its rabid change and great technological advance. The present study is a kind of investigation into the training needs of social-studies teachers at the intermediate stage in Al-Jouf as a step toward enhancing their professional development. What are the training needs for professionally developing social-studies teachers at the intermediate stage in Al-Jouf? Is therefore the main question the paper seeks to answer along with the following sub-questions?

1) What are the modern teaching trends adopted in the Kingdom? Of Saudi Arabia? And to what degree do the adopted trends influence the professional development of social-studies teachers at the intermediate stage in Al-Jouf? 
2) How is systemic planning affected by such trends?

3) In what way can the target teachers benefit from such trends in varying their choice of relevant teaching strategies?

4) How can those trends be regarded in relation to information and communication technology?

5) To what extent can the target teachers associate such trends with the innovative enrichment activities in teaching?

6) In what respect can those teachers exploit such trends in employing the classroom-management skills?

7) How can those modern teaching trends affect the employment of diverse assessment methods?

\subsection{Objectives of the Study}

The present study aims at:

1) Concluding a list of the most effective teaching trends that can serve social-studies teachers at the intermediate stage.

2) Identifying the training needs for the professional development of the target teachers according to the modern Teaching trends concerning the six axes of employing:

A- Systemic planning in teaching.

B- Varied teaching strategies.

C- Information and communication technology.

D- Innovative enrichment activities in teaching.

E- Classroom-management skills.

F- Diverse assessment methods.

3) Showing to what extent the target teachers are in need of training in light of modern teaching trends.

4) Preparing a program that can enhance the professional development and performance of in-service teachers of social studies.

\subsection{Limitations of the Study}

This Study relies on:

1) 120 social-studies teachers at different intermediate schools in Al-Jouf.

2) The modern teaching trends in the six areas of using systemic planning in teaching, varied teaching-strategies, information and communication technology, innovative enrichment activities in teaching, classroom-management skills, and diverse assessment methods.

3) The first term of the academic Hijri year 1432-1433.

\subsection{Importance of the Study}

The importance of this study lies in:

1) Providing a list of the best teaching trends that can serve social-studies teachers at the intermediate stage.

2) Showing to what extent the target teachers are in need of training to cope with the new trends of teaching.

3) Supporting the administrators in charge of the educational system as well as those in charge of preparing training programs in the ministry of education with the findings of this study for developing their training courses.

4) Contributing to the area of field studies with the training needs of social-studies teachers at the intermediate stage in light of modern teaching trends.

5) Dealing with the great challenges facing the educational institutions in an age characterized by its rabid change and unfailing technological advance.

6) Demonstrating the findings of this research for further field studies in the Kingdom of Saudi Arabia. 


\subsection{Approach of the Study}

The present study relies on the descriptive analytic method that fits such a kind of research. This method subtly describes a certain phenomenon and quantitatively analyzes it. Since the researcher's is an attempt to describe and analyze the training needs of social-studies teachers at the intermediate stage in Al-Jouf, the choice of such a method proves to be reliable in:

1) Drawing on previous studies to shape the theoretical frame of the research.

2) Preparing the questionnaire that puts in order the training needs of social-studies teachers at the intermediate stage in Al-Jouf.

3) Demonstrating the findings of the research in order to illustrate to what degree those teachers are in need of training as a step toward enhancing their professional development, in addition to making use of its recommendations in preparing future training Programs.

\section{Terminology of the Study}

Central to the present study are the following terms:

\subsection{Modern Teaching Trends}

A set of modern teaching tasks targeting the employment of systemic planning in teaching, varied teaching strategies, information and communication technology, innovative enrichment activities in teaching, classroom-management skills, and diverse assessment methods.

\subsection{Training Needs of Teachers}

The difference between the expected and the actual performance of teachers, a gap that can be seen by recognizing the performative defects of teachers (Jolanta \& Charzynsk, 2005). Faiza Ahmad Hamada defines the term as a set of changes and developments for reshaping the skills, experiences, and knowledge of teachers to get their best (Hamada, 2004). The training needs of teachers are therefore those information, skills, and trends that should be developed, changed, or modified in relation to the continuing technological advance with an aim to enhance the professional development of teachers.

\subsection{Preparation}

The process of shaping pre-service teachers, undertaken by institutes for teacher qualification, faculties of education, and education-related institutions (Beshara, 1983).

\subsection{Training}

The act of enhancing the professional development of in-service teachers to cope with the continuing change of curricula and methodology rising from the continuing social and technological changes (Ghonima, 1996).

\subsection{Professional Development}

An umbrella term for all forms of educational services introduced to the teacher to enhance his skills, conceptions, and attitudes. Training in-service teachers, therefore, should be a continuing process throughout his career to produce a teacher capable enough of performing the task assigned to him (Gharib \& Hafez, 2012). In this respect, professional development is a well-organized process for reshaping the character of the teacher to the extent that allows him to play his role efficiently.

\subsection{Programs for Developing Teachers}

Any kind of experience that positively affects teachers by correcting their conceptions and activities (Dulrareem, n.d.).

\subsection{Professional Growth}

An educational process teachers voluntarily undergo to learn the best methods that enable them to perform their task properly (Daiz-Maggioli, 2003). In other words, the term refers to a varied set of formal and informal activities designed to support the professional efficiency of teachers so as to be able to overcome the challenges in the field of education. There is a strong relationship between the concept of training and that of professional growth that some educationalists regard the two concepts the same. However, the term professional growth is a broader one as it includes activities directed by educationalists or by in-service teachers themselves as personal endeavors to enrich their knowledge of curricula and related strategies (Beageson, Heuschel, \& Billings, 2003). 


\section{Procedures of the Study}

\subsection{Procedure 1}

Drawing the general frame of the research that includes the introduction, question and plan, objectives, limitations, importance, approach, terminology, and procedures of the study.

\subsection{Procedure 2}

Writing the theoretical frame that includes the literature review and the related references.

\subsection{Procedure 3}

Concluding a list of the most effective teaching trends targeting the six axes, consulting a number of referees to make sure of its validity.

\section{4 Procedure 4}

Designing a questionnaire of the training needs of social-studies teachers at the intermediate stage in Al-Jouf in light of the modern teaching trends list refereed and modified to produce the final form of the questionnaire.

\subsection{Procedure 5}

Selecting a sample of 120 social-studies teachers at different intermediate schools in Al-Jouf.

\subsection{Procedure 6}

Applying the questionnaire to social-studies teachers at the intermediate stage in Al-Jouf to show to what degree those teachers are in need of training to the six axes of the questionnaire.

\subsection{Procedure 7}

Tracing the findings of the questionnaire as reflected by the social-studies teachers at the intermediate stage in Al-Jouf.

\subsection{Procedure 8}

Analyzing and explaining the findings of the study.

\subsection{Procedure 9}

Providing a number of recommendations and suggestions for further future studies.

\section{Theoretical Frame of the Study}

The present study focuses on the training needs of teachers in response to the modern teaching trends and the professional development of teachers.

\subsection{Training Needs of Teachers}

\subsubsection{Concept of Training Needs}

Several studies define training needs as:

A- A set of changes that can enhance the knowledge, experience, performance, behavior, and attitude of a person to be qualified for a certain job.

B- A set of indications showing the difference between the actual and the required performance.

C- A kind of qualitative and quantitative knowledge that promotes the performance of the individual by focusing on his attitudes, skills, and behaviors to have a positive effect on the institution.

D- A set of changes targeting the trainee's knowledge, information, attitude, and behavior for the sake of enhancing his performance to do his task efficiently.

E- A set of efficiencies the teacher should acquire to support his professional performance.

\subsubsection{Importance of Identifying Training Needs}

There are a number of methods attended to when identifying the training needs of teachers. These methods include:

Discussing the importance of identifying training needs, Alaa Eldin Saad Metwally concludes:

A- Effecting change and varying the atmosphere of work.

B- Affecting the planning and evaluation of training programs.

C- Enhancing the professional performance of teachers. 
D- Making best use of the human and material resources.

E- Providing the base on which training rests (Saad Metwally, 2004).

Adel Rasmy Hammad Al-Najdy sums up the importance of identifying the training needs of teachers as follows:

A- Focusing on the target teachers as well as the kind of training needed.

B- Referring to the problems that the teacher faces.

C- Specifying the objectives of training.

D- Putting the training needs in order of priority.

E- Saving time, effort, and money.

F- Identifying the degree of need for training (Hammad Al-Najdy, 2005).

\subsubsection{Methods of Identifying Training Needs}

There are a number of methods attended to when identifying the training needs of teachers. These methods include:

\section{a. Interview}

It is a meeting between the trainer and the trainee in order to identify the training needs of the latter. A number of questions should be prepared and logically arranged to get accurate information about the interviewee, which entails an experienced interviewer (Boyle-Baise, 2002).

\section{b. Efficiency Reports}

These reports reflect the knowledge, experience, attitude, and behavior of a teacher. Reports of this kind are prepared by supervisors to provide a clear picture of a teacher in order to identify his training needs (Hussein, 2004).

\section{c. Questionnaires}

A questionnaire is a way of collecting data, reflecting a person's attitude toward a certain topic. It includes open or closed questions and phrases (Ismael, 2002). It is also a process of identifying the degree of need for training, as it involves a large number of individuals and gives them the opportunity to express their attitudes under no pressure. Though a questionnaire doesn't cost much, it takes a long time for preparation and analysis of data and offers no solutions to the problems it handles.

\section{d. Assessment of Performance}

It is a method of identifying deficiencies by comparing the teacher's actual performance with the expected one in order to identify his training needs (Al-Taany, 2002). There are a number of questions that help to identify the training needs of teachers in light of modern teaching trends:

A- Does the called-for professional development of teachers solve the problems of education?

B- Can training be the way toward realizing the goals of education?

C- Are there reliable criteria for identifying and satisfying the training needs of teachers?

Yes should be the answer to the earlier questions in order to identify the training needs of teachers in light of modern teaching trends (Linda \& John, 2005).

\section{Modern Teaching Trends}

\subsection{Concept of Modern Teaching Trends}

Modern teaching trends can be defined as a spontaneous applied science taking into account the different components of the educational system - the teacher, the student, the educational administrators, and the family - to achieve the called-for goals (Kamal \& Meabad, 2010).

\subsection{Importance of Modern Teaching Trends}

Many educational institutions attend to modern teaching trends because of:

A- The failure of the schools that follow traditional educational systems.

B- The detachment of the educational process from the rabid cadence of the world around.

C- The lower academic achievement of students in comparison to that of those preceding them.

D- The wide gap between scientific research and the real issues of education. 
E- The inefficiency of teachers in general.

F- The bad behaviors of students.

Modern teaching trends emerge as a direct outcome of:

\subsubsection{World Change}

There appears the so-called "informative economy" that simply means the insertion of technology into the process of production and services exchange. This early-twentieth-century term refers to the exchange of information as "an article". The development program of the United Nations defines "informative economy" as the production, propagation, and employment of information in all fields of society, which requires the improvement of human faculties and the placement of such faculties in their proper location. This article flourishes with the help of globalization and the vast advance of networks that it becomes available to all. In other words, information becomes a digital article occupying a first place in societies, entailing subtle marketing in return for high profits and new working opportunities. The success of informative economy relies on the degree of innovation, education represented in human resources, the infrastructure based on technology, and management of the process of putting policies (Al-Mahrouq, 2009). Because of this match between economy and information, this new trend becomes influential on both curricula and methodology.

\subsubsection{Globalization}

Globalization has its remarkable effect on education as it leads to the modification of curricula to suit the new concepts rising as a consequence (Mansour, 2010). It is a challenge requiring an individual capable enough of realizing the world around him and of reacting to the new changes invading our world. Other challenges are those of values and identity, technology, inert powers, scientific research, communication, illiteracy, future studies, translation of sciences, and the overflow of information in addition to the political and economic challenges. These globalization-related challenges stir the different institutions of society into training their members so as to be able to transcend present and future barriers.

\subsubsection{Political Attitudes}

Education is so much influenced by the world's political attitudes that various ideologies find their way into education such as socialism and capitalism. The role of education, in this respect, is to make society accept such ideologies, which results in the modification of curricula and the adoption of reliable teaching strategies.

Associated with modern teaching trends are the following aspects:

\subsubsection{Innovation}

A healthy educational atmosphere is the one that always tries to explore the creative faculties of students. It is also one of the foundations of informative economy that tries to enrich and develop the innovative powers of the individual so as to be able to link together information and economy. Hence is the role of the teacher in exploring and developing such powers in the student, an end that cannot be reached without a well-trained teacher.

\subsubsection{Continuing Self-Education}

This tendency simply means that education is not confined to a certain academic stage or age. A highly qualified teacher can easily instill in the student the seed of self-education and that the student can bear the responsibility of his self-education (Al-Harahesha, 2010). This tendency increases with the focus on the well-educated individual in society in addition to the remarkable advance of technology that requires distinguished human resources. The teacher, in this situation, becomes a guide recommending sources of information to his students though the teacher himself should be a source of information in his own right.

\subsubsection{Cooperative Learning}

This is a very fruitful teaching trend that flourished in the 1990s in which the students cooperate to achieve shared goals. By so doing, cooperation, rather than competition, becomes the dominant spirit. To put the matter at its simplest, cooperative learning is a very successful method of teaching in which small groups of students of different abilities are involved. In this respect, the role of the student is not to learn but to help his colleagues to learn, which creates an atmosphere of excitement and achievement.

The objectives of this modern trend of teaching can be summed up as follows:

A- Getting a good dose of knowledge.

B- Creating an atmosphere of excitement.

C- Developing the sense of working in groups. 
D- Encouraging the social sides in the students.

E- Achieving high self-esteem.

F- Enhancing the ability of the student to reach conclusions.

G- Improving the student's linguistic skills as well as his Communication competence.

The tasks assigned to the students in cooperative learning can be seen in:

A- Identifying and shaping experiences.

B- Collecting and arranging data.

C- Linking previous experiences with the new knowledge.

D- Exerting efforts in helping others.

E- Electronic Learning.

This trend is a breakthrough in methodology due to the increased number of students that may represent a problem to schools. It is a way of learning and can be combined with the traditional way of learning to produce a new exciting method. It suits students that have jobs and are unable to attend classes (Hussein Farag, 2005).

Teachers participating in e-learning should:

A- Be aware of the different methods of learning.

B- Search for reliable methods for regular assessment.

C- Comply with every new shift in the area of his specialization.

D- Be able to make use of technology in serving his educational purposes.

Some modern applied trends of teaching social studies aim at:

A- Moving from the random to the intentional.

B- Moving from the superficial to the more comprehensive.

C- Moving from learning to teaching.

D- Moving from the theoretical to the practical.

E- Moving from passivity to interaction.

F- Moving from the traditional to the innovative.

G- Highlighting the role of feedback in adjusting behaviors.

Commenting on the necessity for training in-service teachers to modern teaching trends, Ali Bin Rashed refers this necessity to:

A- The rabid change in all fields and sciences, which stresses the need to modify school books.

B- The great progress in methodology researches.

C- Social changes and their influence on teaching strategies.

D- The need to encourage the students' scientific thinking based on observation, analysis, deduction, prediction, motivation to academic research, imagination, and innovation — aspects that require a teacher qualified enough to enhance this side in the students.

E- The great technological advance with its various applications that the teacher should be able to use (Al-Din Rashed, 2004).

\section{Professional Development of Teachers}

Teaching is a vocation entailing the teacher's exertion of continuing efforts, his morals, and his sense of responsibility. The teacher should be a model for his students by showing just behaviors and good morals. He should also abide by the ethics of the profession to fulfill the goals and ambitions of society as he is an essential element in the educational process, modifying and developing the content of his subject and choosing the strategy that can achieve the educational goals (Ahmad, 2007).

The teacher should be open minded in order to be able to identify the students' needs, skills, and best methods of dealing with them. He is the students' guide who honestly shows them the most reliable sources of information as well as the right way to self-education. His role is not therefore confined to mere teaching as his role greatly 
changes to catch up with the swift pace of the world around him. In this sense, the professional development of teachers provides a greater part of the solution to many educational issues as teachers directly influence the academic performance and achievement of their students (Al-Din Nasr, 2004).

Strictly speaking, we won't be able to elevate the standard of schools unless there is a professionally developed teacher though there may be good classrooms, curricula, or administration. That is why Arab educational systems have recently given much attention to training in-service teachers in collaboration with universities, and other related institutions.

Training becomes available with the help of the video-conference method that saves much effort, time, and money. Though Arab countries proceed with this endeavor, a number of barriers still stand in the way. Teachers practicing the career against their desire, curricula lacking development, classrooms suffering the increased number of students, and orientation or administration still following traditional methods provide instances of such barriers. Other barriers are represented in the inability of the existing training programs to enhance the process of self-education in the teacher, which hinders his keeping in touch with modern trends of teaching. Another point in case is the concentration on the theoretical side rather than the applied one along with the lack of diverse assessment methods. Hence is the necessity to reconsider the process of education from the university years onward to produce a professional creative teacher capable enough of catching up with the world around him.

Sparks believes that the teacher should be able to identify the needs of the students and to decide which strategy is fit for the educational situation (Sparks, 2000). Thus, the more the teacher is organized, the more organized the students will be. This kind of teacher will also be able to create the proper atmosphere for teaching and to modify his teaching strategy according to the needs of students. Sawa assumes that assessing teachers should be based on the way they employ and modify teaching strategies as well as on their ability to create teaching situations (Sawa, 1995).

Sawa's assumption accords with the present study that seeks to introduce a prescription for a better social-studies teacher at the intermediate stage in Al-Jouf. It is an area that receives little attention by researchers though the level of the student is closely related to that of the teacher. Moreover, some schools begin to produce students lacking even the primary skills of reading, writing, and doing mathematical operations (Hoppensted, 1991). Faculties of education should develop both the theoretical and practical curricula for a more efficient graduate who will participate in achieving quality in the institution he will join. Thus, the following items should be taken into consideration.

\subsection{In-Service Education}

This term refers to the process of training in-service teachers so as to enhance their efficiency that, in turn, leaves its impact on the students.

\subsection{Professional Growth}

The term refers to the set of methods employed to enhance the teacher's efficiency by always identifying and satisfying his professional needs.

In summary, professional development, Hunderson claims, is those training programs that the teacher receives from the day of practicing his career up to his retirement (Hunderson, 1978). It is the number of formal or informal activities that the teacher gets for promoting his professional, behavioral, and cultural sides. Hence is the necessity to conduct this study that targets social-studies teachers at the intermediate stage in Al-Jouf, identifying their training needs in light of modern teaching trends and reaching conclusions that participate in the enhancement of their professional development.

\section{Application of the Study}

To answer the main question of the present study-What are the training needs for professionally developing social-studies teachers at the intermediate stage in Al-Jouf?-A list of modern teaching trends was prepared in relation to previous studies handling the six axes of using:

1) Systemic planning in teaching.

2) Varied teaching strategies.

3) Information and communication technology.

4) Innovative enrichment activities in teaching.

5) Classroom-management skills. 
6) Diverse assessment methods.

The list was given to a number of referees for remarks and modifications in order to produce the final form of this list.

To answer the other questions, a number of steps were taken to identify the training needs of the target teachers:

1) Benefiting from previous studies by getting acquainted with the training needs of social-studies teachers at the intermediate stage.

2) Analyzing the modern teaching trends that social-studies teachers should be aware of.

3) Discussing the list of modern teaching trends with the target teachers to recognize their attitude toward it.

4) Discussing the list of modern teaching trends with the supervisors of social studies to recognize their attitudes toward such modern trends and to what degree teachers are in need of training.

\subsection{Preparing the Questionnaire}

In order for the questionnaire to appear in its final form, a number of steps were taken:

1) A preliminary list of the training needs of social-studies teachers at the intermediate stage in Al-Jouf was analyzed and written as phrases targeting the six axes of the modern teaching trends.

2) The training needs were tested by the following four phrases: Very High (very important), High (important), Average (less important), and Low (not important).

3) The target teachers were asked to mark the phrase that indicates their need degree.

4) A letter explaining the objectives of the study was given and discussed with those teachers for more effective participation in this study.

\subsection{Verifying the Validity of the Questionnaire}

The questionnaire was given to a number of experts in the field of education, especially curricula and methodology, to make sure of its phrasing as well as of the correspondence of each training need with the target axis. Omissions, additions, and modifications of phrases were made till the questionnaire seemed to be valid.

\subsection{Identifying the Objectives of the Questionnaire}

This questionnaire seeks to identify the training needs of social-studies teachers at the intermediate stage in Al-Jouf in light of the modern teaching trends rising in an age dominated by its rabid change and great technological advance.

\subsection{Testing the Steadiness of the Questionnaire}

To test the steadiness of the questionnaire, a pilot study was applied to 12 teachers apart from the subjects of the study. The correspondence of the phrase with the axis ranged between $0.245-0.761$, rates indicating the internal truthfulness of the questionnaire.

The Cronbach equation was used for checking the six axes in addition to the questionnaire as a whole. It showed a validity of $92 \%$.

Table 1. The final form of the questionnaire consists of 88 phrases targeting the six axes

\begin{tabular}{lll}
\hline No. & Axis & Number of Items \\
\hline 1 & Systemic Planning in Teaching & 14 \\
2 & Varied Teaching Strategies & 23 \\
3 & Information and Communication Technology & 12 \\
4 & Innovative Enrichment Activities & 10 \\
5 & Classroom Management Skills & 13 \\
\hline
\end{tabular}




\subsection{Subjects of the Study}

211 social-studies teachers (111 male teachers and 100 female teachers) at 42 intermediate schools for girls and boys in Al-Jouf were selected.

Table 2. Teacher's participation

\begin{tabular}{|c|c|c|c|c|c|c|}
\hline No. & City & $\begin{array}{l}\text { Number of Male } \\
\text { Teachers }\end{array}$ & $\begin{array}{l}\text { Number of Female } \\
\text { Teachers }\end{array}$ & $\begin{array}{l}\text { Number of Male } \\
\text { Subjects }\end{array}$ & $\begin{array}{l}\text { Number of Female } \\
\text { Subjects }\end{array}$ & $\begin{array}{l}\text { Total Number of } \\
\text { Subjects }\end{array}$ \\
\hline 1 & Sakaka & 50 & 40 & 30 & 22 & 52 \\
\hline 2 & Swair & 20 & 15 & 8 & 10 & 18 \\
\hline 3 & Dumat Al-Jandal & 31 & 25 & 15 & 18 & 33 \\
\hline 4 & Tabarjal & 10 & 20 & 7 & 10 & 17 \\
\hline 5 & Total Number & 111 & 100 & 60 & 60 & 120 \\
\hline
\end{tabular}

\subsection{Procedures of Applying the Questionnaire}

The questionnaire in its final form was distributed to 211 teachers. 138 forms were given back and 18 ones were excluded for lacking data. Thus, 120 forms were selected for study during the first term of the academic hijri year 1432, belonging to 60 male teachers and 60 female teachers. The questionnaire was applied to the subjects of the study to identify their training needs in light of modern teaching trends through the phrases: Very High (very important), High (important), Average (less important), and Low (not important). The SPSS program for providing and analyzing data was used to show the degree of need for each of the six axes.

\subsection{Findings of the Study}

The findings of the questionnaire can be shown as follows:

1) The training needs of social-studies teachers at the intermediate stage in Al-Jouf were identified through the repetition of the phrases referring to the degree of need as well as the relative weights of items.

2) The number of repeated phrases was multiplied by the degree given to each of the four phrases $(0 / 1 / 2 / 3)$.

3) The total mark of each training need was divided by 360 (the highest degree of training need), and the outcome was multiplied by 100 to get the percentage. Thus, from $80 \%$ upward indicates a very important training need, from $60 \%$ up to $80 \%$ indicates an important training need, and from $40 \%$ up to $60 \%$ indicates a less important training need less than $40 \%$ indicates that the teachers are in no need of training.

The training needs of social-studies teachers at the intermediate stage in Al-Jouf can be put in the following descending order.

Table 3. The use of systemic planning in teaching

\begin{tabular}{|c|c|c|c|c|}
\hline No. & Training Needs for systemic planning in teaching & Relative Weight & Order & Need Degree \\
\hline 1 & $\begin{array}{l}\text { Inserting activities into the teaching plan and linking the lesson with } \\
\text { experiences and situations }\end{array}$ & 0.962 & 1 & Very High \\
\hline 2 & Designing various exploratory activities satisfying the needs of students & 0.954 & 2 & Very High \\
\hline 3 & $\begin{array}{l}\text { Linking the elements of the lesson plan with the number of experiences } \\
\text { expected from the teaching situation }\end{array}$ & 0.936 & 3 & Very High \\
\hline 4 & $\begin{array}{l}\text { Putting a well-organized plan for the sources of learning that can be } \\
\text { used with students inside and outside the classroom }\end{array}$ & 0.927 & 4 & Very High \\
\hline 5 & $\begin{array}{l}\text { Linking the general objectives of the course with those of each unit and } \\
\text { lesson }\end{array}$ & 0.919 & 5 & Very High \\
\hline 6 & $\begin{array}{l}\text { Following the order of priority in the implementation of the teaching } \\
\text { process according to the objectives of the course }\end{array}$ & 0.892 & 6 & Very High \\
\hline 7 & Designing Activities that allow the use of various teaching strategies & 0.881 & 7 & Very High \\
\hline
\end{tabular}




\begin{tabular}{|c|c|c|c|c|}
\hline & such as cooperative learning and peer education & & & \\
\hline 8 & $\begin{array}{l}\text { Analyzing the concepts, skills, and tasks of the content in an organized } \\
\text { way that can be understood by students }\end{array}$ & 0.869 & 8 & Very High \\
\hline 9 & Putting an organized plan for the lesson & 0.834 & 9 & Very High \\
\hline 10 & Changing the general objectives of the course to those of behaviors & 0.785 & 10 & High \\
\hline 11 & $\begin{array}{l}\text { Linking the behavioral objectives of the lesson with the process of } \\
\text { assessing students }\end{array}$ & 0.724 & 11 & High \\
\hline 12 & Searching for extra sources that help to draw the lesson plan & 0.676 & 12 & High \\
\hline 13 & $\begin{array}{l}\text { Planning for teaching according to adequate information about the topic } \\
\text { and the students }\end{array}$ & 0.643 & 13 & High \\
\hline 14 & $\begin{array}{l}\text { Putting a well-organized plan for the strategies and teaching aids to be } \\
\text { used for fulfilling the objectives of the lesson }\end{array}$ & 0.625 & 14 & High \\
\hline
\end{tabular}

\section{Discussion}

After presenting the results, you are in a position to evaluate and interpret their implications, especially with respect to your original hypotheses. Here you will examine, interpret, and qualify the results and draw inferences and conclusions from them. Emphasize any theoretical or practical consequences of the results (When the discussion is relatively brief and straightforward, some authors prefer to combine it with the Results section, creating a section called Results and Discussion.).

As shown in the above table, Responses to 19 items of this axis get $80 \%$ upward (Very High), which indicates a very important training need. Responses to the 4 other items get more than $60 \%$ (High), which indicates an important training need. Accordingly, most items of this axis are of great importance to social-studies teachers at the intermediate stage in Al-Jouf.

Using varied teaching strategies in introducing concepts and skills to students and using teaching strategies based on the different levels of intelligence occupy the first places among the high training needs of this axis as they show relative weights of 0.973 and 0.971 . Occupying the last place is using teaching strategies based on reciprocal teaching as it shows a relative weight of 0.689 .

Table 4. Axis 3: The use of information and communication technology

\begin{tabular}{|c|c|c|c|c|}
\hline No. & Training Needs for Information and Communication Technology & Relative weight & Order & Need Degree \\
\hline 1 & Browsing the internet in teaching social studies & 0.989 & 1 & Very High \\
\hline 2 & Using things from the environment in teaching social studies & 0.986 & 2 & Very High \\
\hline 3 & Using the power point program in displaying the lesson & 0.978 & 3 & Very High \\
\hline 4 & Using computer programs in teaching social studies & 0.916 & 4 & Very High \\
\hline 5 & $\begin{array}{l}\text { Using computer programs in the process of assessment at all stages of } \\
\text { education }\end{array}$ & 0.903 & 5 & Very High \\
\hline 6 & Using audio and video methods in teaching social studies & 0.814 & 6 & Very High \\
\hline 7 & Using pictures and posters in teaching social studies & 0.753 & 7 & High \\
\hline 8 & Using models and samples in teaching social studies & 0.722 & 8 & High \\
\hline 9 & Using interactive video in teaching social studies & 0.703 & 9 & High \\
\hline 10 & Using practical techniques of education in teaching social studies & 0.687 & 10 & High \\
\hline 11 & Using the email in teaching social studies & 0.668 & 11 & High \\
\hline 12 & $\begin{array}{l}\text { Using field techniques such as field visits and scientific journeys in teaching } \\
\text { social studies }\end{array}$ & 0.663 & 12 & High \\
\hline
\end{tabular}


As shown in the above table, Responses to 6 items of this axis get $80 \%$ upward (Very High), which indicates a very important training need. Responses to the 6 other items get more than $60 \%$ (High), which indicates an important training need. Accordingly, most items of this axis are of great importance to social-studies teachers at the intermediate stage in Al-Jouf.

Browsing the internet and using things from the environment in teaching social studies occupy the first places among the high training needs of this axis as they show relative weights of 0.989 and 0.986 . Occupying the last place is using field techniques such as field visits and scientific journeys in teaching social studies as it shows a relative weight of 0.663 .

Table 5. Axis 4: The use of innovative enrichment activities in teaching

\begin{tabular}{|c|c|c|c|c|}
\hline No. & Training Needs for Innovative Enrichment Activities & Relative Weight & Order & Need Degree \\
\hline 1 & Designing enrichment activities to support distinguished students & 0.943 & 1 & Very High \\
\hline 2 & $\begin{array}{l}\text { Using diverse learning sources and technological methods to get } \\
\text { information }\end{array}$ & 0.908 & 2 & Very High \\
\hline 3 & $\begin{array}{l}\text { Varying the students participation in getting information through field } \\
\text { visits, journeys, reading, and research }\end{array}$ & 0.856 & 3 & Very High \\
\hline 4 & Preparing leaflets and posters on some contemporary issues & 0.843 & 4 & Very High \\
\hline 5 & Inserting the subject into diverse learning activities & 0.732 & 5 & High \\
\hline 6 & Designing wall journals on social-studies-related issues & 0.695 & 6 & High \\
\hline 7 & $\begin{array}{l}\text { Benefiting from the potentials of society in carrying out classroom } \\
\text { activities }\end{array}$ & 0.687 & 7 & High \\
\hline 8 & $\begin{array}{l}\text { Holding meetings between students and local-society members to } \\
\text { discuss contemporary social-studies-related issues }\end{array}$ & 0.652 & 8 & High \\
\hline 9 & Linking social studies with the daily issues of students & 0.635 & 9 & High \\
\hline 10 & $\begin{array}{l}\text { Holding competitions to motivate students to participate effectively in } \\
\text { the learning process }\end{array}$ & 0.613 & 10 & High \\
\hline
\end{tabular}

As shown in the above table, Responses to 4 items of this axis get $80 \%$ upward (Very High), which indicates a very important training need. Responses to the 6 other items get more than $60 \%$ (High), which indicates an important training need. Accordingly, most items of this axis are of great importance to social-studies teachers at the intermediate stage in Al-Jouf.

Designing enrichment activities to support distinguished students and using diverse learning sources and technological methods to get information occupy the first places among the high training needs of this axis as they show relative weights of 0.943 and 0.908 . Occupying the last place is holding competitions to motivate students to participate effectively in the learning process as it shows a relative weight of 0.613 .

Table 6. Axis 5: The use of classroom-management skills

\begin{tabular}{lllll}
\hline No. & Training Needs for Classroom-Management Skills & Relative Weight & Order & Need Degree \\
\hline 1 & Developing self-discipline among students & 0.934 & 1 & Very High \\
2 & Treating abnormal behaviors wisely during the lesson & 0.926 & 2 & Very High \\
3 & Using diverse methods for enhancement inside the classroom & 0.918 & 3 & Very High \\
4 & $\begin{array}{l}\text { Helping students to take decisions and mange time through class } \\
\text { activities }\end{array}$ & 0.907 & 4 & Very High \\
5 & $\begin{array}{l}\text { Creating the democratic atmosphere for a well-organized dialogue and } \\
\text { discussion inside the classroom }\end{array}$ & 0.896 & Very High \\
6 & $\begin{array}{l}\text { Accustoming students to the investment of the period time in doing the } \\
\text { tasks assigned to them }\end{array}$ & 0.854 & 6 & Very High \\
\hline
\end{tabular}




\begin{tabular}{lllll}
\hline 7 & Managing the class behavior of students effectively during the lesson & 0.817 & 7 & Very High \\
8 & $\begin{array}{l}\text { Putting regulations inside the classroom for an effective learning } \\
\text { environment }\end{array}$ & 0.764 & 8 & High \\
9 & $\begin{array}{l}\text { Encouraging positive interaction among students } \\
10\end{array} \quad \begin{array}{l}\text { Providing opportunities for independent and cooperative learning inside } \\
\text { the classroom }\end{array}$ & 0.675 & High \\
11 & $\begin{array}{l}\text { Accustoming students to respect the opinions of others } \\
12\end{array} \quad \begin{array}{l}\text { Organizing students inside the classroom in a way that suits the lesson } \\
\text { and the teaching aid employed }\end{array}$ & 0.589 & 11 & High \\
13 & Achieving equality and objectivity when dealing with students & 0.579 & 12 & High \\
\hline
\end{tabular}

As shown in the above table, Responses to 7 items of this axis get $80 \%$ upward (Very High), which indicates a very important training need. Responses to the 4 other items get more than $60 \%$ (High), which indicates an important training need. Accordingly, most items of this axis are of great importance to social-studies teachers at the intermediate stage in Al-Jouf.

Developing self-discipline among students and treating abnormal behaviors wisely during the lesson occupy the first places among the high training needs of this axis as they show relative weights of 0.934 and 0.926 . Occupying the last places are organizing students inside the classroom in a way that suits the lesson and achieving equality and objectivity when dealing with students as they show relative weights of 0.589 and 0.579 .

Table 7. Axis 6: The use of diverse assessment methods

\begin{tabular}{|c|c|c|c|c|}
\hline No. & Training Needs for Diverse Assessment Methods & Relative Weight & Order & Need Degree \\
\hline 1 & Designing diverse innovative methods for assessment & 0.963 & 1 & Very High \\
\hline 2 & Applying the personal assessment process to students & 0.959 & 2 & Very High \\
\hline 3 & $\begin{array}{l}\text { Designing diverse assessment methods to measure the target output of } \\
\text { education }\end{array}$ & 0.941 & 3 & Very High \\
\hline 4 & $\begin{array}{l}\text { Designing preventive and curative activities to cure the weakness of } \\
\text { students as shown by assessment }\end{array}$ & 0.921 & 4 & Very High \\
\hline 5 & Assessing the sentimental and skill aspects of students & 0.884 & 5 & Very High \\
\hline 6 & Applying the accumulated assessment process to students & 0.866 & 6 & Very High \\
\hline 7 & Applying the preparatory assessment process to students & 0.853 & 7 & Very High \\
\hline 8 & Applying the consecutive assessment process to students & 0.829 & 8 & Very High \\
\hline 9 & Using different written exams in the assessment of students & 0.786 & 9 & High \\
\hline 10 & Designing self-assessment methods & 0.773 & 10 & High \\
\hline 11 & Applying the analytic assessment process to teaching social studies & 0.753 & 11 & High \\
\hline 12 & $\begin{array}{l}\text { Using the findings of assessment in developing and enhancing the } \\
\text { performance of students }\end{array}$ & 0.747 & 12 & High \\
\hline
\end{tabular}

As shown in the above table, Responses to 8 items of this axis get $80 \%$ upward (Very High), which indicates a very important training need. Responses to the 4 other items get more than $60 \%$ (High), which indicates an important training need. Accordingly, most items of this axis are of great importance to social-studies teachers at the intermediate stage in Al-Jouf.

Designing diverse innovative methods for assessment, applying the personal assessment process to students, and designing diverse assessment methods to measure the target output of education occupy the first places among the high training needs of this axis as they show relative weights of $0.963,0.959$, and 0.941 . Occupying the last 
place is using the findings of assessment in developing and enhancing the performance of students, as it shows a relative weight of 0.747 .

Table 8 . The findings of the study in details

\begin{tabular}{|c|c|c|c|c|c|}
\hline No. & Axis & $\begin{array}{l}\text { Number of Phrases } \\
\text { (Very High) }\end{array}$ & $\begin{array}{l}\text { Number of } \\
\text { Phrases (High) }\end{array}$ & $\begin{array}{l}\text { Number of } \\
\text { Phrases (Average) }\end{array}$ & $\begin{array}{l}\text { Number of } \\
\text { Phrases (Low) }\end{array}$ \\
\hline 1 & Systemic Planning in Teaching & 19 & 5 & & ----- \\
\hline 2 & Varied Teaching Strategies & 9 & 4 & & ---- \\
\hline 3 & Information and Communication Technology & 6 & 6 & & ---- \\
\hline 4 & Innovative Enrichment Activities & 7 & 4 & 2 & ---- \\
\hline 5 & Classroom-Management Skills & 4 & 6 & & ---- \\
\hline \multirow[t]{2}{*}{6} & Diverse Assessment Methods & 8 & 4 & & ---- \\
\hline & Total Number & 53 & 29 & 2 & ---- \\
\hline
\end{tabular}

1) 53 phrases (Very High) indicate a very important training need for social-studies teachers at the intermediate stage in Al-Jouf. These phrases appear as follows:
a) 9 phrases refer to the use of systemic planning in teaching.
b) 19 phrases refer to the use of varied teaching strategies.
c) 6 phrases refer to the use of information and communication Technology.
d) 7 phrases refer to the use of innovative enrichment activities in teaching.
e) 4 phrases refer to the use of classroom-management skills.
f) 8 phrases refer to the use of diverse assessment methods.

2) 29 phrases (High) indicate an important training need for social-studies teachers at the intermediate stage in Al-Jouf. These phrases appear as follows:

a) 5 phrases refer to the use of systemic planning in teaching.

b) 4 phrases refer to the use of varied teaching strategies.

c) 6 phrases refer to the use of information and communication Technology.

d) 4 phrases refer to the use of innovative enrichment activities in teaching.

e) 6 phrases refer to the use of classroom-management skills.

f) 4 phrases refer to the use of diverse assessment methods.

3) 2 phrases (Average) indicate a less-important training need for social-studies teachers at the intermediated stage in Al-Jouf. These two phrases refer to the use of innovative enrichment activities in teaching.

4) No phrases (Low) appear in the six axes of the questionnaire, which indicates that no training needs are not important.

In light of the above findings, social-studies teachers at the intermediate stage in Al-Jouf are in need of training to the adoption of modern teaching trends in a world characterized by its rabid change and great technological advance especially in the absence of qualitative training courses.

\section{Recommendations and Suggestions}

1) Providing strategies for the enhancement of training in the Kingdom of Saudi Arabia in general and in Al-Jouf in particular.

2) Providing a viable mechanism for the involvement of university experts in teaching and training in the process of training teachers at the primary, intermediate, and secondary stages.

3) Periodically holding training courses to satisfy the training needs of teachers in light of modern teaching trends. 


\section{References}

Ahmad, D. A. (2007). Professional Accreditation of Teachers in Light of the Experiences of Some Developed Countries (p. 34). Alex, Egypt: New University House.

Al-Din Nasr, N. N. (2004). Sustainable Professional Development of In-service Teachers in the Challenges of Globalization. Journal of the Faculty of Education, Zagazig University, Egypt, 46, 231.

Al-Din Rashed, A. M. (2004). Developing Methods of Training Teachers in Light of Modern Educational Trends. In 3rd Educational Conference: Toward a Better Preparation of Future Teachers (pp. 77-78). Faculty of Education, Sultan Qaboos University (Sultanate of Oman).

Al-Harahesha, M. A. (2010, March). Preparing Teachers in Light of Contemporary Global Challenges. In 16th Scientific Conference: The Future of Preparing Teachers at the Faculties of Education and the Efforts of Scientific Organizations in the Process of Development in the Arab World (Vol. 2, p. 490). Egypt.

Al-Hor, A. A.-A., \& Kamal, A. A. (2003). Priorities of Teaching Efficiencies and Training Needs of Teachers at the Preparatory Stage in Qatar from the Teachers' and Supervisors' Point of View. Journal of the Faculty of Education, 18(20), 36.

Al-Mahrouq, M. (2009). The Role of Informative Economy in Reinforcing the Competitive Abilities of Arab Women (p. 23). Arab Labour Organization.

Al-Taany, H. A. (2002). Training, its Concept and Effectiveness: Designing and Evaluating Training Programs (pp. 24-25). Jordan: Al-Shorouq Publishing House.

Beageson, T., Heuschel, M., \& Billings, A. (2003). Washington State Professional Development Planning Guide. In Teacher Professional Development Part 3 (p. 21). Office of Superintendent of Public Instruction, Washington.

Beshara, G. (1983). Requirements of the Scientific and Technological Revolution in Shaping the Professional Development of Teachers. Arab Journal of Education, 3(1), 67.

Boyle-Baise, M. (2002). Multicultural Service Learning: Educating Teachers in Communities (p. 98). New York: Teachers College Press.

Daiz-Maggioli, G. (2003). Professional Development for Language Teachers (p. 2, ERIC Document No. FD-99-Co-0008).

Dulrareem. (n.d.). The characteristics of the Effective Staff. Development Programs. Retrieved from http://www.nj.gov/education/profdev/standards

Gharib, A. A., \& Hafez, A. A.-S. (2012, January). Elements of School Distinction in Light of Education Quality. Journal of Education Quality Studies and Researches Egyptian National Authority for Quality Assurance and Accreditation in Education, 1, 231-232.

Ghonima, M. M. (1996). Policies and Programs of Preparing Arab Teachers and the Structuring of the Educational Process (p. 97). Egyptian: Lebanese Publishing House, Cairo.

Hamada, F. A. (2004, July). Training Needs of Math Teachers at the Primary Stage in Assiut from the Teachers' and Supervisors' Point of View. Journal of the Faculty of Education, 20(2), 299.

Hammad Al-Najdy, A. R. (2005, July 26-27). Training Needs of History Teachers at the Secondary Stage in Sultanate of Oman in light of Contemporary Glabal Trends. In 17th Scientific Conference for Curricula and Criteria Levels (Vol. 1, pp. 398-399). Egyptian Association for Curriculum and Instruction, Ain Shams University.

Hoppensted, E. M. (1991). A Teacher's Guide to Classroom Management. Illinois, U.S.A: Charles C. Thomas Publishers Spring Field.

Hunderson, E. S. (1978). The Evaluation of In-service Teacher Training (pp. 10-12). London: M. Croom Helm.

Hussein Farag, A. A.-L. B. (2005). Methodology in the Twenty-First Century (1st ed., p. 35). Al-Masera Publishing and Distribution House.

Hussein, H. A. (2004). Identifying the Training Needs of Chemistry Teachers at the Agricultural Secondary Stage. In 16th Conference of the Egyptian Association for Curriculum and Instruction (p. 296).

Ismael, M. (2002). Arabic Encyclopedia of Educational and Educational Technology Terms (p. 106). Riyadh: Al-Rushed LTD. 
Jolanta, R., \& Charzynsk, P. (2005, December). Geography Teacher Training in Poland, Faculty of Biology and Earth Sciences. Planet, 45(15), 9.

Kamal, A., \& Meabad, A. (2010). Training Needs of Social-Studies Teachers at the Primary Stage in light of Modern Educational Trends in Teaching. Journal of Studies in Curricula and Methodology, 159, 224.

Linda, D., \& John, B. (2005). Preparing Teachers for a Changing World: What Teachers Should Learn and be Able to Do? In National Academy of Education (1st ed,, p. 19).

Mansour, E. (2010). The Effect of Globalization on Education from the Educational Administration's Point of View. Journal of the Faculty of Education, Ain Shams University, 34(3), 476.

Saad Metwally, A. A.-D. (2004). Developing a Program for Training Math Teachers in Sultanate of Oman in light of contemporary global trends. In 16th Scientific Conference of Egyptian Association for Curriculum and Instruction (p. 410).

Sawa, R. (1995). Teacher Evaluation Policies and Practices: A Summary of a Thesis (pp. 94-95). SSTA Research Center Report.

Sparks, D. (2000, Spring). Issues at the Table: Teacher Quality and Student Achievement Become Bargaining Matters, An Interview with Julia Koppaich. Journal of Staff Development, 21(2).

\section{Copyrights}

Copyright for this article is retained by the author(s), with first publication rights granted to the journal.

This is an open-access article distributed under the terms and conditions of the Creative Commons Attribution license (http://creativecommons.org/licenses/by/4.0/). 